\title{
Contribution of conservation genetics in assessing neotropical freshwater fish biodiversity
}

\author{
Piorski, NM. ${ }^{\mathrm{a}}$, Sanches, A. ${ }^{\mathrm{b}}$, Carvalho-Costa, LF. ${ }^{\mathrm{c}}$, Hatanaka, $\mathrm{.}^{\mathrm{b}}$, \\ Carrillo-Avila, M. ${ }^{\mathrm{b}}$, Freitas, PD. ${ }^{\mathrm{d}}$ and Galetti Jr., PM. ${ }^{\mathrm{b} *}$ \\ a'Departamento de Oceanografia e Limnologia - UFMA, \\ Av. dos Portugueses, s/n, Campus do Bacanga, CEP 65085-580, São Luís, MA, Brazil \\ bDepartamento de Genética e Evolução, Universidade Federal de São Carlos - UFSCar \\ Rodovia Washington Luis, Km 235, CEP 13565-905, São Carlos, SP, Brazil \\ 'Centro de Ciências Agrárias e Ambientais, Universidade Federal do Maranhão - UFMA, \\ BR 222, Km 74, Boa Vista, s/n, CEP 65500-000, Chapadinha, MA, Brazil \\ ${ }^{d}$ Departamento de Biologia Geral, Campus de Ondina, Universidade Federal da Bahia - UFBA, \\ Rua Barão de Jeremoabo, s/n, CEP: 40170-115, Salvador, BA, Brazil \\ *e-mail: galettip@ufscar.br \\ Received March 26, 2008 - Accepted March 26, 2008 - Distributed November 30, 2008
}

\begin{abstract}
Human activities have a considerable impact on hydrographic systems and fish fauna. The present review on conservation genetics of neotropical freshwater fish reveals that DNA analyses have been promoting increased knowledge on the genetic structure of fish species and their response to environmental changes. This knowledge is fundamental to the management of wild fish populations and the establishment of Evolutionary Significant Units capable of conserving genetic integrity. While population structuring can occur even in long-distance migratory fish, isolated populations can show reduced genetic variation and be at greater risk of extinction. Phylogeography and phylogeny have been powerful tools in understanding the evolution of fish populations, species and communities in distinct neotropic environments. Captive fish can be used to introduce new individuals and genes into the wild and their benefits and disadvantages can be monitored through genetic analysis. Understanding how fish biodiversity in neotropical freshwaters is generated and maintained is highly important, as these habitats are transformed by human development and fish communities are increasingly exploited as food sources to sustain a growing human population.
\end{abstract}

Keywords: molecular genetics, fish population, biology conservation.

\section{Contribuição da Genética da Conservação para o conhecimento da biodiversidade dos peixes de água doce neotropicais}

\begin{abstract}
Resumo
Atividades humanas têm um grande impacto sobre os sistemas hidrográficos e a fauna de peixes. A presente revisão em genética da conservação dos peixes de água doce neotropicais revela que as análises de DNA têm promovido um crescimento no conhecimento da estrutura genética das espécies e suas respostas às alterações ambientais. Este conhecimento é fundamental para o manejo das populações de peixes nativos e para o estabelecimento de Unidades Evolutivas Significantes capazes de conservar a integridade genética dessas populações. Enquanto o fenômeno de estruturação de populações pode ocorrer mesmo em peixes migradores de longas distâncias, populações isoladas podem mostrar reduzida variação genética e apresentar grande risco de extinção. Em adição, a filogeografia e a filogenia têm dado importantes contribuições para o entendimento da evolução das populações, espécies e comunidades de peixes em distintos ambientes neotropicais. Populações de cativeiro podem ser utilizadas como fonte de introdução de novos indivíduos e genes no ambiente natural e seus benefícios e desvantagens podem ser monitorados por meio de análises genéticas. É altamente importante, portanto, entender como é gerada e mantida a biodiversidade de peixes de água doce neotropicais, uma vez que os habitats são transformados pelo desenvolvimento humano e as comunidades de peixes têm sido intensamente exploradas como alimento de sustentação desse crescimento das populações humanas.

Palavras-chave: genética molecular, populações de peixes, conservação biológica.
\end{abstract}

\section{Conservation Genetics in Fish}

Biodiversity has been defined in distinct biological organization levels (genetic, species, community and ecosystem) and human activities have been causing considerable impact on all these levels. The impact on genetic diversity is quite critical, as genetic variation is needed for species adaptation and taxa speciation (Hughes et al., 1997).

A population is defined as a group of interbreeding individuals that are separated (isolated) from other 
populations, but can cross-breed when coming into contact (Magoulick and Kobza, 2003). Population genetic variability is usually measured by the number of alleles (genetic variant) and heterozygosity (Juanes et al., 2007). Intra-population genetic variation represents a balance between mutation, genetic drift and natural selection. Genetic variation is generated by mutation and lost by genetic drift, which increases inter-population differentiation due to a finite population size (Hanfling and Brandl, 1998). Thus, genetic drift increases interpopulation genetic variation, whereas gene flow acts in a reverse way (Frankham et al., 2002). Moreover, natural selection can also reduce genetic variation, leading to the fixation of alleles or promoting their retention as a result of balancing or diversifying selection (Frankham, 1996). However, genetic variability is not only influenced by the contemporaneous impact of mutation, genetic drift and selection, but also by historical events (Hanfling and Brandl, 1998).

Habitat reduction and fragmentation increase the risk of genetic drift and reduce gene flow for a number of species, diminishing the genetic variability of local populations, inhibiting the flow of adaptive genes between populations and interrupting the adaptive process throughout the distribution area of these taxa (Templeton et al., 2001). Populations and species having undergone severe population reduction or bottlenecks are more likely to become extinct (Cornuet and Luikart, 1996).

Extensive local fish population reduction has been reported in several South American hydrographical systems (Mateus et al., 2004). Deforestation, dams, silting and pollution have been pointed out as the major agents in the depletion of fish communities. The resilience of fish populations regarding disturbances depends on the adaptation of species and the spatial/temporal arrangement of the refuge. Lancaster and Belyea (1997) define refuge as a place (or time) in which the negative effects of disturbance are lower than in the surrounding area (or time). Consequently, refuge can play a central role in the structure of the aquatic communities (Magoulick and Kobza, 2003).

Along a particular hydrographic system, freshwater fish can constitute a large and panmictic population or can form differentiated genetic populations with enough gene flow between them to maintain metapopulation integrity. Even long-distance migratory fish can exhibit population structuring (Wasko and Galetti, 2002; Hatanaka and Galetti, 2003; Hatanaka et al., 2006). In the context of gene pool conservation, different genetic populations must be considered as independent units to be managed if one wants to conserve the genetic diversity of a species (Waits et al., 1998). Along with intra-population and inter-population genetic variability, knowledge on the precise range of populations is required to determine the adequate geographical scale for conservation and management strategies (Cegelski et al., 2003). These are issues of conservation genetics, some of which are be detailed in the following sections.

\section{Molecular Tools for Conservation Genetics}

A number of molecular markers have been used in fish population studies to assess genetic variation (Strecker et al., 2003; Barroso et al., 2005), population structuring (Hatanaka and Galetti, 2003; Spruell et al., 2003) and the introduction of captive individuals into wild populations (Sanz et al., 2006). A set of characteristics should be considered in the choice of genetic markers: the methodology should be simple and inexpensive, and a large amount of genotyping data is frequently required. Furthermore, from the statistical standpoint, dominance relationships, informative content, neutrality, position on the map and genetic independence are also relevant (Vignal et al., 2002).

Isoenzymatic markers were extensively used in fish population studies mainly from 1970 to 1990 (ToledoFilho et al., 1978; Almeida-Val et al., 1990). Isoenzymes are variant molecular forms of a single enzyme resulting from the presence of more than one gene codifying each of the enzymes. The basic mutational mechanism of isoenzymes involves substitution and insertion/deletion on the DNA level, which may occasionally result in an alteration in the amino acid sequence of the protein and, consequently, an alteration in the nature of the protein structure of the enzyme (Avise, 2004).

The subsequent use of restriction enzymes in DNA cleavage and the emergence of polymerase chain reaction (PCR) (Mullis and Faloona, 1987) associated with other molecular biology methods such as cloning and sequencing have enabled the development of a vast field of molecular markers. There are a number of marker types and we discuss those most often used in conservation genetics of neotropical fish.

Molecular markers often used in conservation genetics include DNA fingerprinting, restriction fragment length polymorphism (RFLP) analysis, mitochondrial and nuclear gene sequencing, and genotyping of different nuclear loci, such as microsatellites and amplified fragment length polymorphisms (AFLPs) (Aitken et al., 2004). Along with these molecular tools, we may include random amplified polymorphism DNA (RAPD) and, more recently, single nucleotide polymorphisms (SNPs).

The RFLP method involves the cleavage of DNA with one or more restriction enzymes (Grodzicker et al., 1974), thereby generating fragments that may vary in number and size between individuals, populations and species (Liu and Cordes, 2004). These differences are attributed to either mutations in the restriction sites or insertions, deletions and rearrangements between these sites. The generated polymorphism is detected by the hybridization of a probe cloned with DNA fragments obtained through the action of one or more restriction enzymes. Besides nuclear DNA markers, the method known as PCR-RFLP has been employed in mitochondrial DNA studies, in which the PCR amplification product of a particular gene is cleaved with restriction enzymes. In 
studies on Brachyplatystoma flavicans (Castelnau, 1855) and Pseudoplatystoma fasciatum (Linnaeus, 1766), for example, the occurrence of distinct population histories has been suggested for both species through PCR-RFLP (Coronel et al., 2004).

The sequencing of mitochondrial DNA fragments has identified high genetic homogeneity between Astyanax altiparanae (Garutti and Britski, 2000) (Prioli et al., 2002) and Prochilodus lineatus (Valenciennes, 1836) (Sivasundar et al., 2001) populations. On the other hand, a high level of genetic variability and the occurrence of panmixia were observed in Colossoma macropomum (Cuvier, 1816) (Santos et al., 2007).

AFLP assays basically consist of the cleavage of total genomic DNA with two restriction enzymes, the binding of the specific adaptors in the terminal regions of the cleaved fragments, pre-selective amplification and selective amplification. In the final step, the amplified fragments are separated in a high-resolution gel on which band analysis is performed (Vos et al., 1995). AFLP has often been used to assess the genetic diversity of captive fish populations (Mickett et al., 2003) as well as the identification of sex-linked markers (Felip et al., 2005) and hybrid species (Tranah et al., 2003). Anonymous DNA sequences have also been PCR amplified through RAPD and can detect a high degree of polymorphism (Welsh and McClelland, 1990; Williams et al., 1990). The advantage of these methods is the production of molecular markers without any previous genome information on the target species. RAPD markers have been extremely useful in studies on population structuring for Brycon hilarii (Valenciennes, 1850) (Sanches and Galetti, 2007), A. altiparanae (Leuzzi et al., 2004), Pimelodus maculatus (Lacepède, 1803) (Almeida et al., 2003), Prochilodus argenteus (Spix and Agassiz, 1829) (Hatanaka and Galetti, 2003) and Brycon orthotaenia (Günther, 1864) (Wasko and Galetti, 2002).

Microsatellites are by far the most currently used molecular markers in genetic studies on fish. These are polymorphic DNA sequences containing short repetitions arranged in tandem (Tautz, 1989), widely distributed in the genome (Litt and Luty, 1989) and found in all organisms studied thus far (Zane et al., 2002). Due to the high level of polymorphism, Mendelian inheritance and the fact that they apparently follow simple evolutionary models, microsatellites have been largely used to access genetic diversity (Strecker et al., 2003; Barroso et al., 2005) and detect population structuring in different fish species (Hatanaka et al., 2006).

One considerable difficulty in the use of microsatellites is the need to isolate and characterize these markers if they are unavailable for the species of interest. Nonetheless, once the primers are available, a large number of individuals can rapidly be genotyped for codominant alleles. A number of studies have also demonstrated that transferability or cross-species amplification (when primers are designed for one species and used on another) is quite efficient between species of the same genus and even between different genera of the same family (Oliveira et al., 2006).

Another promising DNA technology is SNP, which consists of a change in the nucleotide composition of a DNA sequence at a single site (Brookes, 1999). These changes appear to typically occur every 300 to 1,000 bp (Brouillette et al., 2000). Nonetheless, there are a number of limitations in SNP identification when the genome of the organism is poorly understood. Moreover, as a bi-allelic marker, the informative content is relatively low (Vignal et al., 2002). Compared to microsatellites, a large number of SNPs must be analyzed in population studies (Aitken et al., 2004). In catfish, 1,020 SNPs have been identified in 161 genes from the comparison of 849 expressed sequence tags (ESTs) from Ictalurus furcatus (Valenciennes, 1840) with more than 11,000 ESTs from Ictalurus punctatus (Rafinesque, 1818) deposited in the GenBank (He et al., 2003).

Technological advances in DNA markers have had a revolutionary impact on the field of animal genetics, encompassing molecular systematics, evolutionary biology, molecular ecology and conservation genetics. The numerous currently available genetic markers enable rapid access to intra-population and inter-population genetic variability and allow the study of population structuring, kinship analyses and identifying both individuals and species alike. Thus, DNA markers are extremely useful to the development of more adequate management plans for natural neotropical fish populations.

\section{Genetic Variation and Population Structuring on Migratory Freshwater Fish}

It is well known that fish can exhibit movement or migration during some part of their life cycle. Three types of migration are recognized, which are related to spawning, feeding and refuge (Lucas and Baras, 2001). Movement patterns are an important component in the life-history strategies of fish species, constituting the mechanism used to bring individuals into contact with the resources needed to survive and reproduce (Eiler, 1999).

Most commercial fish are long-distance migratory species following extensive migration circuits that they undertake annually for feeding and reproduction (Arnold, 1999). Eggs and early larvae are carried passively by currents to nursery grounds, which are appropriate locales for the development of the juvenile individuals, offering food and refuge from predators (Lowe-McConnel, 1987; Arnold, 1999).

Vagile fish populations with regular interbreeding and passive larval dispersal will likely lack structuring in systems without physical barriers (Avise, 2004). Thus, fish from a particular species are thought to belong to a large panmitic population within a continuous hydrographic system. However, a number of studies have indicated that even vagile species may contain different populations within a hydrographic basin (Wirth and 
Bernartchez, 2001; Narum et al., 2006; Hatanaka et al., 2006; Sanches and Galetti, 2007).

In salmon, for instance, it is widely accepted that information on the natal stream is imprinted in the nervous system of juveniles during downstream migration and, with this information, adults recognize the natal stream during homing migration (Ueda and Shoji, 2002). Homing in salmons has been addressed through hormonal (Kitani et al., 2003), physiological (Ueda and Shoji, 2002), fish marking and recapture analyses (Tilzey, 1999) and an olfactory ability to discriminate the natal stream (Shoji et al., 2000).

Spawning site fidelity is the main factor involved in the genetic structure frequently found in the salmon populations (Ryman and Utter, 1987). Moreover, the similarity between most repeat-spawning dates of marked fish indicates that an underlying, innate mechanism influences migration timing (Shields et al., 2005). It has been demonstrated that the time of spawning in salmonids is highly heritable (Stefanik and Sandheirich, 1999).

Differences in spawning times can also result in the genetic structuring of a species, as observed in herring species (Jorgensen et al., 2005). Different groups that spawn at a same location but at different times are known as spawning waves (McPherson et al., 2003; Jorgensen et al. 2005).

Population structuring has been detected in neotropical freshwater long-distance migratory fish comprising different genetic populations within a single hydrographic system (Sivasundar et al., 2001; Sanches and Galetti, 2007). In $P$. argenteus, an important fishery resource of the São Francisco River Basin, significant differences have been detected during the spawning season between populations separated by approximately $30 \mathrm{~km}$ of continuous waters (Hatanaka and Galetti, 2003; Hatanaka et al., 2006). According to the authors, this migratory fish may constitute different populations coexisting and comigrating along the river main channel. The possibility of a homing instinct was raised by the authors to explain this population structuring (Hatanaka and Galetti, 2003). Similar results were reported for $B$. orthotaenia inhabiting the same river basin (Wasko and Galetti, 2002).

Population structuring found for $P$. argenteus was corroborated by a study using telemetry to monitor the movement of fish in this same region (Godinho and Kynard, 2006). A dualistic migration pattern was found, in which most fish were migratory, using a large total linear home range, whereas some fish were resident, using the same ground for feeding and spawning. Radiotagged fish exhibited very precise spawning-site homing over successive seasons and some fish also presented non-spawning site fidelity.

Some tag/recapture and radio tracking studies have demonstrated that homing is observed in other migratory freshwater fish species in South America, such as P. lineatus (Godoy, 1975), P. argenteus (Godinho and Kynard 2006), Pseudoplatystoma corruscans (Spix and Agassiz, 1829) (Godinho et al., 2007). Therefore, there is evidence that homing may be a widespread behavior among migratory South American fish (Godinho et al., 2007).

A recent genetic study on $B$. hilarii in the Paraguay River Basin found that the genetic composition of a spawning school was significantly more homogenous when compared to the heterogeneity of local populations (Sanches and Galetti, in preparation). According to the authors, a spawning school could represent an interbreeding unit. The genetic homogeneity and differentiation of the spawning school could be supported by mechanisms such as spawning waves (McPherson et al., 2003; Jorgensen et al., 2005) or homing (Ryman and Utter, 1987), which would promote the segregation of different genetic populations during the reproductive season.

Most studies on long-distance migratory fish have identified a weak differentiation between populations, mainly in abundant species with wide geographic distribution and no notable geographical barriers (Wirth and Bernatchez 2001; Jorgensen et al., 2006; Sanches and Galetti, 2007). The degree and pattern of genetic differentiation is related to the amount of gene flow between populations, which, in turn, is the result of the dispersal and reproductive biology of the species (Jorgensen et al., 2006).

Radio-telemetry studies have found that during the period between two consecutive spawning seasons, the spatial distribution of fish is greater, demonstrating that the fish are more dispersed in their environment (Godinho et al., 2007). The lack of population structuring observed in some migratory fish studied during this one-year period (Carvalho-Costa et al, 2008) may be due to overlapping populations, which can hinder structuring patterns. Therefore, sampling spawning populations is advised in studies on genetic structure, as the supposed different populations would segregate during this season at a specific local or time for reproduction. Thus, we must be cautious in coming to conclusions on a lack of differentiation, as there is the risk of considering the existence of a single population, when in fact different genetic populations may cohabitate a particular space (Laikre et al., 2005).

Knowledge on the genetic structure of fish populations is essential to defining priorities for suitable management and conservation (Moritz, 1994). Conservation or fishery management plans with no prior knowledge of genetic structure could result in the overexploitation of some populations or segmentation of populations, and consequently gene pools could be extirpated or the genetic diversity within populations could be reduced (Laikre et al. 2005).

\section{Small Isolated Populations}

Populations structured by habitat fragmentation due to barriers such as roads, dams, waterfalls and climate (drought and rain) have their abundance, dispersal and population size reduced, thereby increasing the risk of extinction (Gross et al., 2004; Letcher et al., 2007). This 
fragmentation can lead to the total or partial isolation of a population, conditioning the response of the individuals. Some authors have described chromosomal differences between populations in a single hydrographic basin that seem to be a recurrent event in distinct taxa having lived in small populations restricted to headwater streams (Moreira-Filho and Bertollo, 1991; Torres et al., 1998). In Hoplias malabaricus (Bloch, 1794), karyotype differences seem to be due to distinct evolutionary histories as a consequence of restricted gene flow (Vicari et al., 2005). The Astyanax genus (Baird and Girard, $1854)$ is characterized by short-distance migration and a stepping-stone model has been claimed to explain low level of gene flow and the genetic differentiation pattern observed among populations (Moysés and AlmeidaToledo, 2002). In Astyanax scabripinnis (Jenyns, 1842) inhabiting different small streams, besides extensive chromosome divergences observed between populations (Moreira-Filho and Bertollo, 1991), a significant population differentiation has also been reported through a molecular analysis between putative isolated populations, although the mechanisms (selection and/or genetic drift) responsible for such genetic differentiation remain unknown (Sofia et al., 2006). Moreover, sex ratio deviation seems to be a common occurrence among this fish group and is likely related to behavioral and ecological strategies to quickly occupy the headwaters in which they live (Gross et al., 2004), but may reduce genetic variation by reducing the effective population number (Frankham et al., 2002) and lead to population differentiation.

Fish from the Rivulidae family are characterized by small populations with physiological adaptations for surviving in temporary ponds that are completely dried up during the summer. In these annual fish, each generation completes its life cycle in the span of a year and survives the dry season in egg form buried in the mud. During the subsequent rainy season, the ponds refill, the eggs hatch and the larvae rapidly grow to sexual maturity and reproduce (Costa, 1998). Little is known on the genetics of killifishes inhabiting the neotropics. Austrolebias cf. adloffi (Ahl, 1922) and Austrolebias viarius (Vaz-Ferreira, Sierra de Soriano and Scaglia de Paulete, 1964) inhabiting the eastern wetlands of Uruguay have had their taxonomy status questioned, as they may hybridize in the laboratory (García et al., 2002). Chromosome and isoenzyme analyses have shown a high genetic similarity between individuals and a reduced inter-taxon heterozygosity likely related to the small population size, genetic drift and inbreeding (García et al., 2002). However, some chromosome and molecular taxon-specific markers are observed, suggesting limited gene flow and reinforcing the occurrence of two separate taxa (García et al., 2002).

Thus, it is well-documented that isolated populations tend to reduce their genetic variability and, consequently, their ability to adapt to environmental changes, thereby restricting their evolutionary potential (Hanfling and Brandl, 1998). Moreover, the consequent inbreeding exposes small populations to the deleterious effects of recessive alleles and inbreeding depression, characterized by early mortality as well as a reduction in fertility and growth rate, which can lead to the extinction of populations (Frankham, 1996).

In contrast, populations that are not completely isolated form a kind of metapopulation with gene flow between them. All the genetic variation of this metapopulation is divided in inter-population and intra-population variability (Hanfling and Brandl, 1998). In these not totally isolated populations, extinction can be prevented if enough immigrants from other areas or populations are available, whereas small, isolated populations are at a greater risk of extinction due to stocasticity, demographic, environmental or genetic effects and have less opportunities for demographic re-colonization from the dispersion of neighboring populations (Frankham et al., 2002).

\section{Phylogeography on Neotropical Fish}

Phylogeography is a field of study concerned with principles and processes governing the geographic distribution of genealogical lineages (Avise, 2004), which enables scrutinizing issues such as the origins of hybrid zones (Hewitt, 2001), introgression (Hubert et al., 2008) and species boundaries (Martínez-Ortega et al., 2004).

To address such issues in animals, inferences are mainly based on reconstructions of species/population gene genealogies through mitochondrial DNA (mtDNA) (Lovejoy and De Araújo, 2000). In this regard, phylogeography has been revealing the history of the diversification of freshwater fish in the neotropics, relating it to events involved in the final establishment of the modern South American rivers between 15 and 10 million years ago (Ma) (Lundberg et al., 1998). These studies have shown how vicariance and coalescence between drainage systems have shaped the evolution of this astonishing fish diversity (Lundberg et al., 1998). However, there is an ongoing debate over the relative importance of such geological events vs. adaptive or ecological speciation in generating this diversity (Moritz et al., 2000). Defenders of geological-based speciation have raised a number of hypotheses for this process (Hubert and Reno, 2006; Hubert et al., 2007) and a general consensus suggests that fish diversification predates Pleistocene climatic fluctuations (Lovejoy and De-Araújo 2000; Sivasundar et al., 2001; Montoya-Burgos, 2003; Moyer et al., 2005; Albert et al., 2006), which is hypothesized for terrestrial organisms speciation.

Indeed, phylogeographic information has thus far indicated a strong influence of geological history on the genetic variation of freshwater fish, in such a way that the null hypothesis for river biogeography expects that evolutionarily closely related species and populations would be found in the same river system (Lovejoy and De-Araújo, 2000; Willis et al., 2007). Nevertheless, other studies indicate the opposite, that is, some populations show close relationships between rather than within system (Hrbek and Larson, 1999; Lovejoy and De-Araújo, 
2000; Sivasundar et al., 2001; Montoya-Burgos, 2003; Turner et al., 2004). River anastomosis during marine regressions, headwater-capture events and direct connections between rivers all provide dispersion opportunities for fish and may explain such patterns, highlighting the complex nature of river drainage history in the neotropics (Lundberg et al., 1998).

Furthermore, phylogeographic studies have provided evidence supporting colonization scenarios in the basins from the recently emerged lands of Central America through lineages coming from South American rivers, immediately following the rising of the Isthmus of Panama (3 Ma) (Bermingham and Martin, 1998; Reeves and Bermigham, 2006) as well as physical factors involved in the contemporaneous distribution of fish species and concordance with key geological events (Hrbeck and Larson, 1999; García et al., 2000; Sivasundar et al., 2001; Turner et al., 2004). Fish phylogeography has also supported deeply divergent monophyletic groups within drainages (Lovejoy and De Araújo, 2000), historical and recent connections between basins, past demographic events (Turner et al., 2004; Reeves and Bermigham, 2006) and ecological factors responsible for diversification (Perdices et al., 2002; Reeves and Bermigham, 2006).

In long-distance migratory fish, inter-basin phylogeographic structure is rarely supposed to be found, although aspects such as migration capability, reproductive biology, historical/contemporaneous physical barriers, ecological and behavior features may play a role in the distribution of lineages. The reasoning is that the genetic diversity of non-migratory species tends to depend on the distance between groups (isolation-by-distance structure model), which could be disregarded in rheophilic fish. Sivasundar et al. (2001) and Batista and Alves-Gomes (2006) found no relationship between haplotype distribution and geography in P. lineatus (a long-distance migratory fish) along the Paraná basin and in Brachyplatystoma rousseauxii (Castelnau, 1855) (a large long-distance migratory catfish) in the Amazon Basin, respectively.

Historical factors seem to be the best explanation for the observed distribution of fish haplotypes in geographic spaces in South America. However, ecological factors have been also considered. Reeves and Bermigham (2006) and Perdices et al. (2002) offer compelling evidence that different ecologies may play a major role in lineage boundaries in Central American basins. Equal opportunities for dispersion via river capture and river anastomosis associated with the different ecologies underlying such lineages may explain the absence of sympathy between the closest evolutionary operational taxonomic units with high niche overlap (Reeves and Bermigham, 2006).

Regarding conservation issues, identifying significant evolutionary units (Moritz, 1994) in which unique adaptations may be evolved in populations is one of the main advances phylogeography offers, as such populations could be considered possible targets for conservation and management purposes. Such historical information on the species/population divergence could help decision makers allocate the scanty financial resources available in neotropical countries for conservation policies more effectively. Thus, such studies constitute efforts to maintain genetic diversity (and the processes responsible for it) and reduce threats of local extinctions, as genetic variation is the substrate for evolutionary adaptation (Frankham et al., 2002). Moreover, understanding the processes that generate biodiversity in neotropical freshwater environments is increasingly important, as these habitats are transformed by development and aquatic species and communities are increasingly exploited for food to support a growing human population (Turner et al., 2004).

\section{Fish Community Structure and Hydrographic Basins}

The community concept is as much disputed as the species concept. Regardless of the various opinions voiced for its definition, the recognition of several community types has been suggested as a guarantee for validating different concepts in particular cases (Brooks and McLennan, 1991). From this standpoint, a community evolution study should consider the interactions between historical and non-historical components, the evolutionary path taken by the community and the integration between phylogenetic information and studies on community organization (Brooks and McLennan, 1991; Webb et al., 2002). In the neotropics, the few studies that have addressed these issues were concerned with local patterns.

Given that communities can be set up by both historical and non-historical events, the species composing a community, on the other hand, will show their own features that should be defined by both competition and environment structure (Tofts and Silvertown, 2000). The structural hypothesis predicts that every hydrographic basin has its unique assemblage of fish, with communities differing in composition. This speaks to the null hypothesis of Vari (1988), according to which each basin is considered an endemism unit. The competition hypothesis, in turn, suggests that fish in a basin should vary because differences are produced by interactions between species. Moreover, the community composition should be defined by historical events controlling the gene flow between basins and turning into endemic units.

Even though the Vari hypothesis is simplistic (Willis et al., 2007), endemicity is an important concept to the vicariance biogeography (Wiley, 1988; Brooks and McLennan, 1991) of freshwater fish because it encompasses the idea of species evolution in isolation. By definition, an endemic species is found only in one geographic area and nowhere else (Cox and Moore, 1993).

Areas of endemism for South American freshwater fish have been proposed in at least three important studies. Gery (1969) recognized eight faunistic regions: 1) Orinoco-Venezuelan; 2) Magdalenean; 3) TransAndean; 4) Andean; 5) Paranean; 6) Patagonian; 
7) Guianean-Amazonian and 8) East-Brazilian, formed by the São Francisco River, coastal rivers in northeastern Brazil above the São Francisco River and coastal rivers in southeastern Brazil.

Vari (1988) identified 14 endemic regions for the Curimatidae family. On the western slopes of the Andes, besides the endemic areas of Rio Magadalena and Lago Maracaibo basin, four subregions were recognized, defined by the Atrato, Patia, Guayas and Chira Rivers. On the Atlantic side of South America, the author described eight major areas of endemism: Orinoco, Guianas, Amazon, Northeast, São Francisco, Coastal, Upper Paraná and Paraguay. The author considered both northeastern Brazil endemic, and the São Francisco hybrid regions, where components of curimatid fauna would be either more closely related to species in the Amazon or to elements of coastal fauna. This previously defined northeastern Brazil endemic region has now been split into three regions corresponding to the Maranhão River, the Parnaíba River Basin and coastal rivers north of the São Francisco River (Lundberg et al., 1998). In recent years, new fish species have been described in this region (Piorski et al. 2008; Triques, 1999; Ferraris and Vari, 1999).

A number of studies have incorporated phylogenetic data in describing biogeographical patterns in South American fish. Using mtDNA sequences, Sivasundar et al. (2001) have raised a phylogenetic hypothesis for four species of the genus Prochilodus (Spix and Agassiz, 1829) in four different hydrographic basins: Magdalena (Colombia), Amazon (Brazil and Peru) and Paraná. The hypothesis is congruent with geologic evidence of the initial separation of the Magdalena River Basin from the clade [Orinoco + (Amazonas + Paraná) . Coronel et al. (2004) have described the relationships between populations of two species with wide distribution in South America - B. flavicans and P. fasciatum - based on nuclear and mtDNA markers and hypothesize restricted gene flow events between the populations studied. Evidence of rapid radiation in a short period of time was reported for neotropical cichlids by López-Fernández et al. (2005), using a molecular data set.

Descriptive and/or comparative studies on community genetics (Antonovics, 1992) in neotropical fish are rare. This is not a local deficiency. Webb et al. (2002) have pointed out the lack of integration between evolutionary biology and community ecology in spite of the increasing availability of molecular and analytical methods making the elucidation of phylogenetic relationships easier and more reliable. Most community ecology studies are highly reductionistic (Chase and Knight, 2003). The analysis of the evolution of behavioral characters of Gymnogeophagus (Miranda Ribeiro, 1918) species from the La Plata Basin is one of the few examples of such studies in South America (Wimberger et al., 1998). In the paper, a superficial discussion based on molecular data is employed to explain the relationships between mitochondrial phylogenetics, biogeography and evolution of parental care that can be attached to issues of the coevolutionary paradigm (Brooks and McLennan, 1991). Lassala and Renesto (2007) were more specific in comparing heterozygosity values between fish groups with different reproductive strategies. These authors have noted that non-migratory fish with no parental care had the highest mean heterozygosity values, in contrast with long-distance migratory and non-migratory species with parental care or internal fecundation strategies.

A critical early stage in speciation is the evolution of genetic differences between populations (Orr and Smith, 1998). What it is important is how these differences are sustained and/or how they are stressed. Thus, for neotropical fish, for which there are few studies on community genetics, we would be working only on the genetic differences between populations. Most studies lack integration between genetics and ecology, which would allow more reliable approaches and forecasts for conservation biology. One possible approach would be to evaluate the ecological factors with regard to the genetic differences observed between community members (Orr and Smith, 1998).

\section{Captive Populations, Restocking and Fish Conservation}

Captive fish populations and their restocking in the wild can be used as a conservation strategy for endangered populations (Frankham et al., 2002). Although not well documented, restocking has been used in a number of hydrographic systems in Brazil, mainly associated to environmental programs following the construction of hydroelectric dams (IBAMA, 2008).

As mentioned above, small threatened populations lose most of their genetic variation as a consequence of genetic drift and inbreeding, and such a low level of genetic variability may reduce the mean fitness of a population, affecting its viability, particularly, if parasites or competitors are present (Vrijenhoek, 1994). The highly homozygous fish Poeciliopsis Regan, 1913 presented a decline in fertility and growth rates when compared to more heterozygous populations (Vrijenhoek, 1989). Restocking can be carried out to increase the effective population size and genetic variation of threatened local populations (Frankham et al., 2002).

However, the introduction of captive individuals to an open environment necessarily involves some impact, and restocking has been cited as damaging to native ecosystems, mainly affecting local biodiversity (Roll et al., 2007). Non-native populations may affect indigenous species by competing for resources, preying on native fauna, significantly altering the habitat and its relationships, and bringing genetic introgression to native populations (Ribeiro et al. 2007; Sanz et al., 2006). Introduced or translocated populations can also transfer pathogens, cause community changes, facilitate the introduction of other taxa and promote a series of deleterious effects to local populations (Roll et al., 2007). 
In recent years, however, a large number of researchers have attempted to characterize attributes for successful fish introduction (Rosecchi et al., 2001; Kollar and Lodge, 2002; Marchetti et al., 2004). The success of a restocking program depends on the ecological and genetic features of each population. The restocking of a species must occur by using a genetic stock that is as appropriate as possible. The use of a wide number of breeding adults from a local genetic population is encouraged in order to avoid inbreeding and ensure local genetic integrity. However, a high level of introgression of captive population genes can occur, as has been described in local Salmo trutta Linnaeus, 1758 populations, in which introgression may be destroying their evolutionary pattern due to the introduction of the same exogenous gene pool to all wild local populations (Sanz et al., 2006). Moreover, translocations of species or populations into areas where they have not naturally occurred could have an adverse impact on other local native populations and/or species due to the increase in the restocked population (DAFF, 2008).

According to the Instituto Brasileiro do Meio Ambiente e dos Recursos Naturais Renováveis (Brazilian Environmental Agency) (IBAMA, 2008) and the Guidelines for Restocking Native Fish Species under the Recreational Fishing Community Grant Program (DAFF, 2008), an ideal restocking program must follow certain steps: First, the habitat requirements of the target species must be determined. Second, a survey must be carried out on the current population and habitat for the species, identifying threats to the target species. The cause of the original decline of the species population for the area must be known and addressed. Restocking is carried out to assist population recovery. Population monitoring is performed to assess the effect of restocking and habitat restoration must be performed as well. Moreover, the genetic variation levels of both captive stocks potentially useful for restocking and wild populations should also be monitored (Vrijenhoek, 1994; Roll et al., 2007).

The overall purpose of restocking is a permanent and sustainable increase in the target population or species. A program for monitoring the results and genetic analyses through molecular markers can be very helpful (Sanz et al., 2006).

\section{Final Considerations}

Conservation genetics on neotropical freshwater fish is a very stimulating, promising field of study using molecular tools, statistics and bioinformatics to answer biological and ecological questions directly related to the conservation biology of particular populations/species. The ever-increasing human impact on hydrographic systems and fish fauna make conservation concerns a priority. Technological advances in DNA analyses have been promoting increasing knowledge on the genetic structure of fish species and the processes responsible for species maintenance or changes, encompassing molecular systematics, evolutionary biology, molecular ecology and conservation genetics. A number of currently available genetic markers enable rapid access to intra-population and inter-population genetic variability and allow the study of population structuring and kinship analyses as well as the identification of both individuals and species alike. Phylogeography and phylogeny based on molecular analysis can be very useful for describing evolution patterns in fish populations, species and communities in distinct neotropic hydrological systems. Knowledge on the population structuring of a particular fish species is fundamental to the establishment of Evolutionary Significant Units, can conserve genetic integrity and should be used by ecologists in the future. Thus, DNA markers are extremely useful to the development of more adequate management plans for natural neotropical fish populations. Captive fish can be used to introduce new individuals and genes into the wild and their advantages and disadvantages can be monitored through genetic analyses. Understanding how fish biodiversity in neotropical freshwaters is generated and maintained is highly important, as these habitats are transformed by human development, and fish species and communities are increasingly exploited as food sources to sustain a growing human population.

Acknowledgements - The authors are grateful to the Brazilian agencies Conselho Nacional de Desenvolvimento Científico e Tecnológico (CNPq), Fundação de Amparo à Pesquisa do Estado de São Paulo (FAPESP), Coordenação de Aperfeiçoamento de Pessoal de Nível Superior (CAPES), Fundação O Boticário de Proteção à Natureza and Banco da Amazônia (BASA) for financial support; the Instituto Brasileiro do Meio Ambiente e dos Recursos Naturais Renováveis (IBAMA) for the authorization of fish collection.

\section{References}

AITKEN, N., SMITH, S., SCHWARZ, C. and MORINS, PA., 2004. Single nucleotide polymorphism (SNP) discovery in mammals: a targeted-gene approach. Mol. Ecol., vol. 13, no. 6, p. 1423-1431.

ALBERT, JS., LOVEJOY, NR. and CRAMPTON, WGR., 2006. Miocene tectonism and the separation of cis- and trans-Andean river basins: Evidence from Neotropical fishes. J. South Am. Earth sci, vol. 21, no. 1-2, p. 14-27.

ALMEIDA, FSD., SODRÉ, LMK. and CONTEL, EPB., 2003. Population structure analysis of Pimelodus maculatus (Pisces, Siluriformes) from the Tietê and Pananapanema Rivers (Brazil). Genet. Mol. Biol., vol. 26, no. 3, p. 301-305.

ALMEIDA-VAL, FVM., SCHWANTES, MLB. and VAL, AL., 1990. Ldh Isozymes. In Amazon Fish. I. Electrophoretic studies on two species from Serrassalmidae family: Mylosoma duriventris and Colossoma macropomum. Comp. Biochem. Physio., vol. 95B, p. 77-84.

ANTONOVICS, J., 1992. Toward community genetics. In FRITZ, RS. and SIMMS, EL. (Eds.). Plant resistance to herbivores and pathogens: ecology, evolution, genetics. Chicago, Illinois: University of Chicago Press.

ARNOLD, G., 1999. Unravelling mechanisms of fish migration: a 30-year perspective. In HANCOCK, DA., SMITH, DC. and 
KOEHN, JD. (Eds.). Fish Movement and Migration. Bendigo: Fisheries Research \& Development Corporation, p. 7-21.

AVISE, JC., 2004. Molecular markers, natural history and evolution. 2 ed. Massachusetts: Sinauer Associates, p. 541.

BARROSO, RM., HILSDORF AWS., MOREIRA, HLM., CABELLO, PH. and TRAUB-CSEKO, YM., 2005. Genetic diversity of wild and cultured populations of Brycon opalinus (Cuvier, 1819) (Characiforme, Characidae, Bryconiae) using microsatellites. Aquaculture, vol. 247, no. 1-4, p. 51-65.

BATISTA, JS. and ALVES-GOMES, JA., 2006. Phylogeography of Brachyplatystoma rousseauxii (Siluriformes - Pimelodidae) in the Amazon Basin offers preliminary evidence for the first case of "homing" for an Amazonian migratory catfish. Genet. Mol. Res., vol. 5, no. 4, p. 723-740.

BERMINGHAM, E. and MARTIN, AP., 1998. Comparative mtDNA phylogeography of neotropical freshwater fishes: testing shared history to infer the evolutionary landscape of lower Central America. Mol. Ecol., vol. 7, no. 4, p. 499-517.

BROOKES, AJ., 1999. The essence of SNPs. Gene, vol. 234, no. 2, p. 177-186.

BROOKS, DR. and MCLENNAN, DA., 1991. Phylogeny, ecology and behavior: a research program in comparative biology. Chicago: The University of Chicago Press.

BROUILLETE, JA., ANDREW, JR. and VENTA, PJ., 2000. Estimate of nucleotide diversity in dogs with a pool-and-sequence method. Mamm. Genome, vol. 1, no. 12, p. 1079-1086.

CARVALHO-COSTA, LF., HATANAKA, T. and GALETTI JR, PM. 2008. Evidence of lack of population substructuring in the Brazilian freshwater fish Prochilodus costatus. Genet. Mol. Biol., vol 31, no.1 (suppl), p. 377-380.

CEGELSKI, CC., WAITS, LP. and ANDERSON, NJ., 2003. Assessing population structure and gene flow in Montana wolverines (Gulo gulo) using assignment-based approaches. Mol. Ecol., vol. 12, no. 11, p. 2907-2918.

CHASE, JM. and KNIGHT, TM., 2003. Community genetics: toward a synthesis. Ecology, vol. 84, no. 3, p. 580-582.

CORNUET, JM. and LUIKART, G., 1996. Description and power analysis of two tests for detecting recent population bottlenecks from allele frequency data. Genetics, vol. 144, no. 4, p. 2001-2014.

CORONEL, JS., MAES, JE., CLAUS, S., VANDAMME, PA. and VOLCKAERT, FAM., 2004. Differential population history in the migratory catfishes Brachyplatystoma flavicans and Pseudoplatystoma fasciatum (Pimelodidae) from the Bolivian Amazon assessed with nuclear and mitochondrial DNA markers. J. Fish Biol., vol. 65, no. 3, p. 859-868.

COSTA, WJEM., 1998. Phylogeny and classification of Rivullidae revised: Origin and evolution of annualism and miniaturization in rivulid fishes (Cypriniodontiformes: Aplocheiloidei). J. Comp. Biol., vol. 3, no. 1, p. 33-94.

COX, CB. and MOORE, PD., 1993. Biogeography: an ecological and evolutionary approach. Oxford: Blackwell Science.

DAFF, 2008. Recreational Fishing Community Grants Program. Fish Restocking Guidelines. Australia: Department of Agriculture, Fisheries and Forest. [20 February, 2008]. Available from: http://www.daff.gov.au/_data/assets/pdf_file/0015/6081/ stocking_guidelines.pdf.
EILER, JH., 1999. Fish movements - the missing piece. In HANCOCK, DA., SMITH, DC. and KOEHN, JD. (Eds.). Fish Movement and Migration. Bendigo: Fisheries Research \& Development Corporation, p. 85-93.

FELIP, A., YOUNG, WP., WHEELER, PA. and THORGAARD GH., 2005. An AFLP-based approach for the identification of sex-linked markers in rainbow trout (Oncorhynchus mykiss). Aquaculture, vol. 247, no. 1-4, p. 35-43.

FERRARIS JR, CJ. and VARI, RP., 1999. The South American catfish genus Auchenipterus Valenciennes, 1840 (Ostariophysi: Siluriformes: Auchenipteridae): monophyly and relationships, with a revisionary study. Zool. J. Linn. Soc., vol. 126, no. 4, p. $387-450$

FRANKHAM, R., 1996. Relationship of genetic variation to population size in wildlife. Conserv. Biol., vol. 10, no. 6, p. $1500-1508$.

FRANKHAM, R., BALLOU, JD. and BRISCOE, DA., 2002. Introduction to Conservation Genetics. 1ed. Cambridge: Cambridge University Press, 642 p.

GARCÍA, G., PEREIRA, A., CARRERA, I., and MARQUEZ, A., 2002. Genetic relationships in a complex of Cynolebias species (Cypriniodontiformes, Rivulidae) from eastern Uruguay and Southern Brazil. Bol. Soc. Zool. Uruguay, vol. 13, no. 2, p. 1-11.

GARCÍA, G., WLASIUK, G. and LESSA, EP., 2000. High levels of mitochondrial cytochrome b divergence in annual killifishes of the genus Cynolebias (Cyprinodontiformes, Rivulidae). Zool. J. Linn. Soc., vol. 129, no. 1, p. 93-110.

GERY, J., 1969. The fresh-water fishes of South America. In FILTKAU, EJ. (Eds.). Biogeography and ecology in South America. Dordrecht: W. Junk Publisher.

GODINHO, AL. and KYNARD, B., 2006. Migration and spawning of radio-tagged zulega Prochilodus argenteus in a dammed Brazilian River. Tran. Am. Fish. Soc., vol. 135, no. 3, p. $811-824$

GODINHO, AL., KYNARD, B. and GODINHO, HP., 2007. Migration and spawning of female surubim (Pseudoplatystoma corruscans, Pimelodidae) in the São Francisco river, Brazil. Environ. Biol. Fishes, vol. 80, n. 4, p. 421-433.

GODOY, MP., 1975. Peixes do Brasil, Subordem Characoidei. Bacia do Rio Mogi Guassu. Vol. II. Piracicaba: Franciscana Piracicaba, 397 p.

GRODZICKER, T., WILLIAMS, J., SHARP, P. and SAMBROOK, J., 1974. Physical mapping of temperaturesensitive mutations of adenovirus. In Cold Spring Harbor Symposium Quantitative Biology, vol. 39, p.439-446. New York: Cold Spring Harbor.

GROSS, MC., SCHNEIDER, CH., MATIELLO, MCA., LEITE, ML., BERTOLLO, LAC. and ARTONI, RF., 2004. Population structure, fluctuating asymmetry and genetic variability in an endemic and highly isolated Astyanax fish population (Characidae). Genet. Mol. Biol., vol. 27, no. 4, p. 529-535.

HANFLING, B. and BRANDL, R., 1998. Genetic variability, population size and isolation of distinct populations in the freshwater fish Cottus gobio L. Mol. Ecol., vol 7, no. 12, p. $1625-1632$.

HATANAKA, T. and GALETTI JR., PM., 2003. RAPD markers indicate the occurrence of structured populations in a 
migratory freshwater fish species. Genet. Mol. Biol., vol. 26, no. 1, p. 19-25.

HATANAKA, T., HENRIQUE-SILVA, F. and GALETTI JR., PM., 2006. Population structuring in a migratory freshwater fish Prochilodus argenteus (Characiformes, Prochilodontidae) from São Francisco River. Genetica, vol. 126, no. 1-2, p. 153-159.

HE, C., CHEN, L., SIMMONS, M., LI, P., KIM, S., and LIU, ZJ., 2003. Putative SNP discovery in interspecific hybrids of catfish by comparative EST analysis. Anim. Genet., vol. 34, no. 6, p. $445-448$.

HEWITT, GM., 2001. Speciation, hybrid zones and phylogeography - or seeing genes in space and time. Mol. Ecol., vol. 10 , no. 3, p. 537-549.

HRBEK, T. and LARSON, A., 1999. The evolution of diapause in the killifish family Rivulidae (Atherinomorpha, Cyprinodontiformes): a molecular phylogenetic and biogeographic perspective. Evolution, vol. 53, no. 4, p. $1200-1216$.

HUBERT, N. and RENNO, JF., 2006. Historical biogeography of South American freshwater fishes. J. Biogeogr., vol. 33, no. 8, p.1414-1436.

HUBERT, N., DUPONCHELLE, F., NUÑEZ, J., GARCIADAVILA, C., PAUGY, D., RENNO, J-F., 2007. Phylogeography of the piranha genera Serrasalmus and Pygocentrus: implications for the diversification of the Neotropical ichthyofauna. Mol. Ecol., vol. 16, no. 10, p. 2115-2136.

HUBERT, N., TORRICO, JP., BONHOMME, F., RENNO, JF., 2008. Species polyphyly and mtDNA introgression among three Serrasalmus sister-species. Mol. Phylogenet. Evol., vol. 46, no. 1, p. 375-381.

HUGHES, JB, DAILY GC and EHRLICH PR., 1997. Population diversity: its extent and extinction. Science, vol. 278, no. 5338, p. 689-694.

IBAMA, 2008. Fauna. Devolução dos Animais à Natureza. Available from: http://www.ibama.gov.br/fauna/devolucao.htm. [accessed 15 February, 2008].

JORGENSEN, HBH., HANSEN, MM., BEKKEVOLD, D., RUZZANTE, DE. and LOESCHCKE, V., 2005. Marine landscape and population genetic structure of herring (Clupea harengus L.) in the Baltic Sea. Mol. Ecol., vol. 14, no. 10, p. 3219-3234.

JUANES, F., PEREZ, J. and GARCIA-VAZQUEZ, E., 2007. Reproductive strategies in small populations: using Atlantic salmon as a case study. Ecol. Freshw. Fish, vol. 16, no. 4, p. $468-475$.

KITANI, T., MATSUMOTO, S., YAMADA, H., AMANO, M., IWATA, M. and UEDA, H., 2003. Changes in GnRH levels in the brain and pituitary gland during migrations of sockeye salmon and chum salmon. Fish. Physiol. Biochem., vol. 28, no. $1-4$, p. 269-270.

KOLAR, CS. and LODGE, DM., 2002. Ecological predictions and risk assessment for alien fishes in North America. Science, vol. 298, no. 5596, p. 1233-1236.

LAIKRE, L., PALM, S. and RYMAN, N., 2005. Genetic population structure of fishes: implications for coastal zone management. Ambio, vol. 34, no. 2, p. 111-119.
LANCASTER, J. and BELYEA LR., 1997. Nested hierarchies and scale-dependence of mechanisms of flow refugium use. $J$. N. Am. Benthol. Soc., vol. 16, no. 1, p. 221-238.

LASSALA, MDP. and RENESTO, E. 2007. Reproductive strategies and genetic variability in tropical freshwater fish. Genet. Mol. Biol., vol. 30, no. 3, p. 690-697.

LETCHER, BH., NISLOW, KH., COOMBS, JA., O'DONNELL, MJ. and DUBREUIL, TL., 2007. Population response to habitat fragmentation in a stream-dwelling brook trout population. PLoS ONE, vol. 2, no. 11 e1139.DOI:10.1371/journal.pone.0001139.

LEUZZI, MSP., ALMEIDA, FS. and ORSI, ML., 2004. Analysis by RAPD of the genetic structure of Astyanax altiparanae (Pisces, Characiformes) in reservoirs on the Paranapanema River, Brazil. Genet. Mol. Biol., vol. 27, no. 3, p. 355-362.

LITT, M. and LUTY, JA., 1989. A hypervariable microsatellite revelead by in vitro amplification of a dinucleotide repeat within the cardiac muscle actin gene. Am. J. Hum. Genet., vol. 44, no. 3 , p. $397-401$.

LIU, ZJ. and CORDES, JF., 2004. DNA marker technologies and their applications in aquaculture genetics. Aquaculture, vol. 238 , no. $1-4$, p. 1-37.

LOPEZ-FERNANDEZ, H., HONEYCUTT, RL., WINEMILLER, KO. 2005. Molecular phylogeny and evidence for an adaptive radiation of geophagine cichlids from South America (Perciformes: Labroidei). Mol. Phylogenet. Evol., vol. 34 , no. 1 , p. $227-244$

LOVEJOY, NR. and De-ARAÚJO, MLG., 2000. Molecular systematics, biogeography and population structure of Neotropical freshwater needlefishes of the genus Potamorrhaphis. Mol. Ecol., vol. 9, no. 3, p. 259-268.

LOWE-MCCONNELL, RH., 1987. Ecological studies in tropical fish communities. New York, USA: Cambridge University Press.

LUCAS, MC. and BARAS, E., 2001. Migrations of freshwater fishes. Oxford: Blackwell Science.

LUNDBERG, JG., MARSHALL, LG., GUERRERO, J., HORTON, B., MALABARBA, MCSL. and WESSELINGH, F. 1998. The stage for Neotropical fish diversification: a history of tropical South American rivers. In MALABARBA, LR., REIS, RE., VARI, RP., LUCENA, ZMS. and LUCENA, CAS. (Eds.). Phylogeny and classification of Neotropical fishes. Porto Alegre: EDIPUCRS.

MAGOULICK, DD. and KOBZA, RM., 2003. The role of refugia for fishes during drought: a review and synthesis. Freshw. Biol., vol. 48, no. 7, p. 1186-1198.

MARCHETTI, MP., MOYLE, PB. and LEVINE R., 2004. Alien fishes in California watersheds: characteristics of successful and failed invaders. Ecol. Appl., vol. 14, no. 2, p. 587-596.

MARTIN, AP. and BERMINGHAM, E., 1998. Systematics and evolution of lower Central American cichlids inferred from analysis of cytochrome $b$ gene sequence. Mol. Phylogenet. Evol., vol. 9, no. 2, p. 192-203.

MARTÍNEZ-ORTEGA, MM., LUIS, D., ALBACH, DC., ELENA-ROSSELLO, JA. and RICO, E., 2004. Species boundaries and phylogeographic patterns in cryptic taxa inferred from AFLP markers: Veronica subgen. Pentasepalae (Scrophulariaceae) in the Western Mediterranean. Syst. Botany., vol. 29 , no. 4 , p. $965-986$ 
MATEUS, LAF., PENHA, JMF. and PRETERE, M., 2004. Fishing resources in the rio Cuiabá basin, Pantanal do Mato Grosso, Brazil. Neotrop. Ichthyol., vol. 2, no. 4, p. 217-227.

MCPHERSON, AA., STEPHENSON, RL. and TAGGART, CT., 2003. Genetically different Atlantic herring Clupea harengus spawning waves. Mar. Ecol. Prog. Ser., vol. 247, no. 4, p. 303-309.

MICKETT, K., MORTON, C., FENG, J., LI, P., SIMMONS, M., CAO, D., DUNHAM, RA. and LIU, Z., 2003. Assessing genetic diversity of domestic populations of channel catfish (Ictalurus punctatus) in Alabama using AFLP markers. Aquaculture, vol. 228 , no. $1-4$, p. 91-105.

MONTOYA-BURGOS, JI., 2003. Historical biogeography of the catfish genus Hypostomus (Siluriformes: Loricariidae), with implications on the diversification of Neotropical ichthyofauna. Mol. Ecol., vol. 12, no. 7, p. 1855-1867.

MOREIRA-FILHO, O. and BERTOLLO, LAC. 1991. Astyanax scabripinnis (Pisces, Characidae): a species complex. Braz. J. Genet., vol. 14, no. 2, p. 331-357.

MORITZ, C., 1994. Defining evolutionary significant units for conservation. Trend. Ecol. Evol., vol. 9, no. 10, p. 373-375.

MORITZ, C., PATTON, JL., SCHNEIDER, CJ., SMITH, TB., 2000. Diversification of rainforest faunas: an integrated molecular approach. Ann. Rev. Ecol. Syst., vol. 31, p. 533-563.

MOYER, GR., WINEMILLER, KO., MCPHEE, MV., TURNER, TF., 2005. Historical demography, selection, and coalescence of mitochondrial and nuclear genes in Prochilodus species of northern South America. Evolution, vol. 59, no. 3, p. 599-610.

MOYSÉS, CB. and ALMEIDA-TOLEDO, LF., 2002. Restriction fragment length polymorphism of mitochondrial DNA among five freshwater fish species of the genus Astyanax (Pisces, Characidae). Genet. Mol. Biol., vol. 25, no. 4, p. 401-407.

MULLIS, K. and FALOONA, F., 1987. Specific synthesis of DNA in vitro via a polymerase catalysed chain reaction. Methods Enzymol., vol. 55, p. 335-350.

NARUM, SR., BOE, S., MORAN, P. and POWELL, M., 2006. Small-scale genetic structure and variation in steelhead of the Grande Ronde River, Oregon, USA. Trans. Am. Fish. Soc., vol. 135 , no. 4 , p. $979-986$.

OLIVEIRA, JO., PÁDUA, JG., ZUCCHI, MI. and VENCOVSKY, R., 2006. Origin, evolution and genome distribution of microsatellites. Genet. Mol. Biol., vol. 29, no. 2, p. 294-307.

ORR, MR. and SMITH, TB., 1998. Ecology and speciation. TREE, vol. 13, no. 12, p. 502-506.

PERDICES, A., BERMINGHAM, E., MONTILLA, A. and DOADRIO, I., 2002. Evolutionary history of the genus Rhamdia (Teleostei: Pimelodidae) in Central America. Mol. Phylogenet. Evol., vol. 25, no. 1, p. 172-189.

PIORSKI, NM., GARAVELLO, JC., ARCE H., M. and PÉREZ, MHS., 2008. Platydoras brachylecis, a new species of thorny catfish (Siluriformes: Doradidae) from northeastern Brazil. Neotrop. Ichthyol., vol. 6, no. 3, p. 481-494.

PRIOLI, SMAP., PRIOLI, AJ., JÚLIO JR., HF. and PAVANELLI, CS., 2002. Identification of Astyanax altiparanae (Teleostei, Characidae) in the Iguaçu River, Brazil, based on mitochondrial
DNA and RAPD markers. Genet. Mol. Biol., vol. 25, no. 4, p. 421-430.

REEVES, RG. and BERMINGHAM, E., 2006. Colonization, population expansion, and lineage turnover: phylogeography of Mesoamerican characiform fish. Biol. J. Linn. Soc., vol. 88, no. 2, p. 235-255.

RYMAN, N. and UTTER, F., 1987. Population Genetics and Fishery Management. Washington: Sea Grant Publications/ University of Washington Press, Seattle and London.

RIBEIRO, F., ELVIRA, B., COLLARES-PEREIRA, MJ. and MOYLE, PB, 2007. Life-history traits of non-native fishes in Iberian watersheds across several invasion stages: a first approach. Biological Invasions, vol. 10, no. 1, p. 1233-1236.

ROLL, U., DAYAN, T., SIMBERLOFF, D. and GOREN, M., 2007. Characteristics of the introduced fish fauna of Israel. Biol. Invasions, vol. 9, no. 7, p. 813-824.

ROSECCHI, E., THOMAS, F. and CRIVELLI. AJ., 2001. Can life-history traits predict the fate of introduced species? A case study on two cyprinid fish in Southern France. Freshw. Biol., vol. 46 , no. 6 , p. 845-853.

SANCHES, A. and GALETTI JR., PM., 2007. Genetic evidence of population structuring in the neotropical freshwater fish Brycon hilarii (Valenciennes, 1850). Braz. J. Biol., vol. 67, no. 4, p. 889-895.

SANTOS, MCF., RUFFINO, ML. and FARIAS, IP., 2007. High levels of genetic variability of the tambaqui Colossoma macropomum (Cuvier, 1816) in the main channel of the Amazon River. J. Fish. Biol., vol. 71, no. Supplement A, p. 33-44.

SANZ, N., CORTEY, M., PLA, C. and GARCÍA-MARÍN, JL., 2006. Hatchery introgression blurs ancient hybridization between brown trout (Salmo trutta) lineages as indicated by complementary allozymes and mtDNA markers. Biol. Conserv., vol. 130, no. 2, p. 278-289.

SHIELDS, BA., STUBBING, DN., SUMMERS, DW., GILES, N., 2005. Temporal and spatial segregation of spawning by wild and farm-reared brown trout, Salmo trutta L., in the River Avon, Wiltshire, UK. Fish. Manag. Ecol., vol. 12, no. 1, p. 77-79.

SHOJI, T., UEDA, H., OHGAMI, T., SAKAMOTO, T., KATSURAGI, Y., YAMAUCHI, K. and KURIHARA, K., 2000. Amino acids dissolved in stream water as possible home stream odorants for masu salmon. Chem. Senses, vol. 25, no. 5, p. $533-540$

SIVASUNDAR, A., BERMINGHAM, E. and ORTÍ, G., 2001. Population structure and biogeography of migratory freshwater fishes (Prochilodus: Characiformes) in major South American rivers. Mol. Ecol., vol. 10, no. 2, p. 407-417.

SOFIA, SH., SILVA, CRM., GALINDO, BA., ALMEIDA, FS., SODRÉ, LMK. and MARTINEZ, CBR., 2006. Population genetic structure of Astyanax scabripinnis (Teleostei, Characidae) from an urban stream. Hydrobiologia, vol. 553, no. 1 , p. $245-254$.

SPRUELL, P., HEMMINGSEN, AR., HOWELL, PJ., KANDAL, N. and ALLENDORF, FW., 2003. Conservation genetics of bull trout: geographic distribution of variation at microsatellite loci. Conserv. Genet., vol. 4, no. 1, p. 17-29.

STEFANIK, EL. and SANDHEINRICH, MB., 1999. Differences in spawning and emergence phenology between stocked and wild populations of brown trout in southwestern 
Wisconsin Streams. N. Am. J. Fish. Manag., vol. 19, no. 4, p. $1112-1116$.

STRECKER, U., BERNATCHEZ, L. and WILKENS, H., 2003. Genetic divergence between cave and surface populations of Astyanax in Mexico (Characidae, Teleostei). Mol. Ecol., vol. 12, no. 3, p. 699-710.

TAUTZ, D., 1989. Hypervariability of simple sequences as a general source for polymorphic DNA markers. Nucl. Acids Res., vol. 17, no. 16, p. 6463-6471

TEMPLETON, AR., ROBERTSON, RJ., BRISSON, J. and STRASBURG, J., 2001. Disrupting evolutionary processes: the effect of habitat fragmentation on collared lizards in the Missouri Ozarks. Proc. Natl. Acad. Sci. USA, vol. 98, no. 10, p. $5426-5432$.

TILZEY, RDJ., 1999. Environmental cues in the reproductive migrations of brown trout (Salmo trutta) in Lake Eucumbene, New South Wales. In HANCOCK, DA., SMITH, DC. and KOEHN, JD. (Eds.). Fish Movement and Migration. Bendigo: Fisheries Research \& Development Corporation, p. 112-122.

TOFTS, R. and SILVERTOWN, J., 2000. A phylogenetic approach to community assembly from a local species pool. Proc. Royal Soc., vol. 267, p. 363-369.

TOLEDO FILHO, SA., RIBEIRO, AF. and FORESTI, F., 1978. Function of Lactate-Dehydrogenase C Gene in Astyanax (Pisces, Characidae). Egypt. J. Genet. Cytol., vol. 7, no. 1, p. 52-55.

TORRES, RA., FORESTI, F. and OLIVEIRA, C., 1998. Comparative cytogenetic studies in alopatric populations of Tricomycterus paolence (Siluriformes, Tricomycteridae). Cytologia, vol. 63, no. 1, p. 107-114

TRANAH, GH., BAGLEY, M., AGRESTI, JJ. and MAY, B., 2003. Development of codominant markers for identifying species hybrids. Conserv. Genet., vol. 4, no. 4, p. 537-541.

TRIQUES, ML. 1999. Three new species of Rhamphichthys Müller et Troschell, 1846 (Ostariophysi: Gymnotiformes: Rhamphichthyidae). Rev. Fr. Aquariol., vol. 26, no. 1-2, p. 1-6.

TURNER, TF., MCPHEE, MV., CAMPBELL, P., WINEMILLER, KO., 2004. Phylogeography and intraspecific genetic variation of prochilodontid fishes endemic to rivers of northern South America. J. Fish. Biol., vol. 64, p. 186-201.

UEDA, H. and SHOJI, T., 2002. Physiological mechanisms of homing migration in salmon. Fish. Sci., vol. 68, suppl. 1, p. $53-56$

VARI, RP., 1988. The Curimatidae, lowland neotropical fish family (Pisces: Caharaciformes); distribution, endemism and phylogenetic biogeography. In VANZOLINI, PE. and HEYER, WR. (Eds.). In Proceedings of a workshop on neotropical distribution patterns. Rio de Janeiro: Academia Brasileira de Ciências.

VICARI, MR., ARTONI, RF. and BERTOLLO, LAC., 2005. Comparative cytogenetics of Hoplias malabaricus (Pisces, Erythrinidae): A population analysis in adjacent hydrographic basins. Genet. Mol. Biol., vol. 28, no. 1, p. 103-110.
VIGNAL, A., MILAN, D., SANCRISTOBAL, M. and EGGEN, A., 2002. A review on SNP and other types of molecular markers and their use in animal genetics. Genet. Sel. Evol., vol. 34, no. 3, p. 275-305

VOS, P., HOGERS, R., BLEEKER, M., REIJANS, M., VAN DE LEE, T., HORNES, M., FRIJTERS, A., POT, J., PELEMAN, J., KUIPER, M., ZABEAU, M., 1995. AFLP: a new technique for DNA fingerprinting. Nucl. Acids Res., vol. 23, no. 21, p. 4407-4414.

VRIJENHOEK, RC., 1989. Genotypic diversity and coexistence among sexual and clonal forms of Poeciliopsis. In OTTE, D. and ENDLER, J. (Eds.). Speciation and its consequences. Sunderland MA, p. 368-400

VRIJENHOEK, RC., 1994. Genetic diversity and fitness in small population. In LOESCHCKE, V., TOMIUK, J. and JAIN, SK. (Eds.). Conservation Genetics. Birkhäuser Verlag Basel: Switzerland, p. 38-53

WAITS, LP, TALBOT, SL, WARD, RH. and SHIELDS, GF., 1998. Mitochondrial DNA phylogeography of the north american brown bear and implications for conservation. Conserv. Biol., vol. 12, no. 2, p. 408-417.

WASKO, AP. and GALETTI Jr., PM., 2002. RAPD analysis in the Neotropical fish Brycon lundii: genetic diversity and its implications for the conservation of the species. Hydrobiologia, vol. 474 , no. $1-2$, p. 131-137.

WEBB, CO., ACKERLY, DD., MCPEEK, MA. and DONOGHUE, MJ. 2002. Phylogenies and community ecology. Ann. Rev. Ecol. Syst., vol. 33, p. 475-505.

WELSH, J. and McCLELLAND, M., 1990. Fingerprinting genomes using PCR with arbitrary primers. Nucl. Acids Res., vol. 18 , no. 24 , p. $7213-7218$

WILEY, EO., 1988. Vicariance biogeography. Ann. Rev. Ecol. Syst., vol. 19, p. 513-542.

WILLIAMS, JGK., KUBELIK, AR., LIVAK, KJ., RAFALSKI, JA. and TINGEY, SV., 1990. DNA Polymorphisms amplified by arbitrary primers are useful as genetic markers. Nucl. Acids Res., vol. 18, no. 22, p. 6531-6535.

WILLIS, SC., NUNES, MS., MONTAÑA, CG., FARIAS, IP. and LOVEJOY, NR., 2007. Systematics, biogeography, and evolution of the Neotropical peacock basses Cichla (Perciformes: Cichlidae). Mol. Phylogenet. Evol., vol. 44, p. 291-307.

WIMBERGER, PH., REIS, RE. and THORNTON, KR., 1998. Mitochondrial phylogenetics, biogeography, and evolution of parental care and mating systems in Gymnogeophagus (Perciformes: Cichlidae). In MALABARBA, LR., REIS, RE., VARI, RP., LUCENA, ZMS. and LUCENA, CAS. (Eds.). Phylogeny and classification of neotropical fishes. Porto Alegre: EDIPUCRS

WIRTH, T. and BERNATCHEZ, L., 2001. Genetic evidence against panmixia in the European eel. Nature, vol. 409, no. 22, p. $1037-1040$.

ZANE, L., BARGELLONI, L. and PATARNELLO, T., 2002. Strategies for microsatellite isolation: a review. Mol. Ecol., vol. 11, no. 1, p.1-16. 